\title{
COASTAL EROSION AND TOURISM: THE CASE OF THE DISTRIBUTION OF TOURIST ACCOMMODATIONS AND THEIR DAILY RATES
}

\author{
Davis P. de Paula ${ }^{1}$, Jailson C. Lima', Eduardo L. Barros ${ }^{2}$, Jader de O. Santos ${ }^{3}$ \\ ${ }^{1}$ Ceará State University (UECE)/Postgraduate Program in Geography (PROPGEO)/ Laboratory of Coastal and Oceanic \\ Geology and Geomorphology (LGCO), Campus do Itaperi, 60.714-903, Fortaleza-CE, Brazil \\ Environment Chief-Scientist Program (FUNCAP)/Ceará Environment Secretariat (SEMA); LGCO, Campus do Itaperi, \\ 60.714-903, Fortaleza-CE, Brazil \\ ${ }^{3}$ Ceará Federal University (UFC)/Postgraduate Program in Geography (POSGEO) and PRODEMA/ Campus do Pici, \\ 60455-760, Fortaleza-CE, Brazil \\ *Corresponding author: davis.paula@uece.br \\ Received: February 24 ${ }^{\text {th }}, 2021$ / Accepted: August 2nd, 2021 / Published: October 1st, 2021 \\ https://DOI-10.24057/2071-9388-2021-018
}

\begin{abstract}
Beaches are key territories for tourist development but at risk of impacts of climate change-specifically with the consequent intensification of coastal erosion. This study examines the effects of coastal erosion on the distribution of lodging facilities and the value of daily rates practiced on the beaches of Tabuba and Cumbuco on the northeast coast of Brazil. The methodology comprises collecting information on the means of accommodation (distribution and daily rate), quantifying coastline variation and measuring the field to validate data. A total of $13.9 \mathrm{~km}$ of coastline were analyzed; erosion tendency was observed in $26.8 \%$ of the coast (9.0\% erosion, $14.4 \%$ intense erosion, and $3.4 \%$ severe erosion). With the highest erosion rates, Tabuba's Beach has a low density in accommodation distribution and daily rates practiced in tourism. Cumbuco's Beach, conversely, has a lower risk of erosion, and the means of accommodation are concentrated. Coastal erosion has affected tourism development in Caucaia, influencing the choice of tourism accommodation entrepreneurs. the results indicate that there is a clear concentration of tourist accommodations in areas without notorious problems with coastal erosion, influencing in the distribution of tourist facilities and their daily rates. So, there is a direct connection does exist between local tourism system income and the beaches with problems with coastal erosion.
\end{abstract}

KEYWORDS: Beach erosion, sun-beach tourism, shoreline, coastal landscape, coastal management

CITATION: Davis P. de Paula, Jailson C. Lima, Eduardo L. Barros, Jader de O. Santos (2021). Coastal Erosion And Tourism: The Case Of The Distribution Of Tourist Accommodations And Their Daily Rates . Geography, Environment, Sustainability, Vol. 14, No 3, p. 110-120 https://DOl-10.24057/2071-9388-2021-018

ACKNOWLEDGMENTS: The authors would like to thank the National Council for Scientific and Technological DevelopmentCNPQ (Scholarship PQ 310246 / 2019-9, PQ 312000 / 2020-0 and Master's Scholarship) and the Post-Graduate Program in Geography (PROPGEO / UECE) for their support. This study was supported by the Cearense Foundation for Support for Scientific and Technological Development (FUNCAP) through FCT AAC No. 02 / SAICT / 2017 (Project Holistic Approach to the simulation of long-term evolution of the coast) and the Laboratory of Coastal Geology and Geomorphology and Oceanic of the UECE.

Conflict of interests: The authors reported no potential conflict of interest.

\section{INTRODUCTION}

The tourism industry is one of the economic activities that most emerge in the scenario of global economic growth. Some studies suggest that the growth of the economy and tourism activity are interdependent but not stable (Antonakakis et al. 2015; Dogru and Bulut 2018; Lakshmi and Shaji 2016; Seghir et al. 2015). The tourism industry is one of the sectors of the economy that produces the most indirect impacts, inducing the formation of human capital to meet its needs (Dogru and Sirakaya-Turk 2017).

In many territories, tourism is the main source of income generation, employment, and social development (Lee and Chang 2008). According to the World Tourism Organization (WTO), in 2018, there were 1.407 million international arrivals of tourists worldwide, generating revenue of US\$ 1.462 billion. The WTO projects a growth of 3.3\% per year until 2030; however, the values should be revised after the COVID-19 pandemic.

Indeed, understanding the causal relationship between tourism and economic growth is important in the implementation of public policies and strategies aimed at sustainable development (Burak et al. 2004; Phillips and Jones 2006). However, other causal relationships must be considered in the local development of this activity, such as coastal erosion. Sandy beaches, for example, occupy onethird of the coastlines and are environments that provide leisure, recreation, and tourism opportunities, which are important spaces for the social and economic benefits of residents and tourists (Luijendijk et al. 2018). 
The beaches are landscapes in a constant process of metamorphosis by geological, oceanographic, hydroclimatic, and anthropogenic factors. In addition, sealevel rise induced by climate change can have a negative impact on coastal dynamics, driving the process of coastal erosion (Nicholls 2011; Stive et al. 2009; Zhang et al. 2004;). Vousdoukas et al. (2020) indicate that half of the world's sandy beaches could disappear by 2100 if the pessimistic scenario of rising sea levels materializes. This situation could hinder the development of global tourist activity. However, it is necessary to consider that this study does not consider the regional and local dynamic factors, and there may be an extrapolation in the results.

In this sense, the environmental quality of the beach is a determining factor in choosing the tourist destination, and visitors are concerned with the natural values of the beach and environmental degradation (Lima and Paula 2017; Roca et al. 2009; Semeoshenkova and Newton 2015). In this case, the challenge has been to reconcile environmental quality with the development of the tourism industry (Holden 2000). Roca et al. (2009) highlighted that the relationship between beach users and the environment is complex and, at times, confusing, as the satisfaction and pleasure of leisure and recreation activities are directly and indirectly affected by the environmental quality of the place. The environmental quality of the beaches and adjacent environmental systems has thus become a crucial factor of competitiveness among the numerous tourist destinations of the sun and beach modality (Mihalic 2000). Currently, several authors (Fuchs et al. 2014; Ladhari and Michaud 2015; Peña-Alonso et al. 2017) claim that the quality of infrastructure and services offered to users of coastal tourism is also a significant factor of attractiveness. Therefore, the environmental quality of the beaches must be accompanied by satisfactory levels of comfort and assistance for the development of leisure and recreation activities associated with beach tourism. In this process of valuing coastal areas in terms of tourist activity, there is a significant increase in demand for tourism products and services via online platforms, with numerous travelers who increasingly adhere to online channels (e.g., Booking.com) to conduct their research and define their itineraries and accommodation during their travel (Wu and Law 2019).

In Brazil, as in other parts of the world, beaches have become the main spaces for the development of tourism practice (Cruz 2003), with the need to protect them, something that may seem antagonistic today (Meulen et al. 2001). The erosion of sandy beaches represents a real threat to coastal economies (Alexandrakis et al. 2015; Phillips and Jones 2006). This is especially the case for those territories that derive their family income from tourist services, being a major factor for the socio-economic development of tourist communities, as is the case in most coastal cities in northeast Brazil.

This study is based on an approach that combines information about the state of the beaches (eroding, accreting, and stable) and the spatial distribution of the means of accommodation. In general, it is common for studies to address the cost of coastal erosion of sandy beaches from coastal protection measures that will be built. This study thus begins with an understanding of the general aspects of coastal erosion from the reflexes on the coastline and how these results influence the spatial distribution of the means of accommodation as a provider of tourist services. The hypothesis is that lodging facilities are installed in areas with better environmental quality, that is, coastal areas without signs of erosion.
TOURISM AND COASTAL EROSION IN CAUCAIA COAST (NORTHEAST BRAZIL)

Tourism in Ceará has emerged in Brazil, as pointed out in the Monthly Survey of Services (PMS) conducted by the IBGE, with an average growth rate of $4.8 \%$, recorded in December 2019. The study also points out that this growth had a direct influence on the new flights implemented since the creation of the hub air in Fortaleza. As a reflex, the number of foreign passengers increased by $102 \%$ from May 2018 to April 2019. In 2019, the tourist indicators of Ceará indicate that there was a $5.5 \%$ growth in activity in relation to the previous year, with 3.7 million tourists and an impact of US\$384,915.36 on the state economy (SETUR-CE 2020). This economic activity represented, in 2019, 12.6\% of the Gross Domestic Product (GDP) of the State of Ceará. The coast as a tourist destination in Ceará concentrates $82 \%$ of the tourists who visit the state, $57 \%$ of the tourists who visit only the city of Fortaleza, 27\% who visit Fortaleza and some other location, and 16\% who visit exclusively, other Ceará destinations, with emphasis on Caucaia, Aquiraz, Aracati, and Beberibe (SETUR-CE 2020).

Tourism in Caucaia is a reflection of public policies adopted by the Government of the State of Ceará and the Federal Government, in which the tourism industry has been treated with strategic economic activity. Over the past 30 years, the state has invested more than US\$ 185 million in tourism development projects and actions in Ceará through the Regional Tourism Development Program (Araujo and Pereira 2011; Silva and Lima 2015). Investments are initially concentrated in the road and air infrastructure, then in tourism products and the commercialization of destinations (e.g., Cumbuco, Jericoacoara, and Canoa Quebrada).

The coast of the municipality of Caucaia, located in the Metropolitan Region of Fortaleza-RMF (northeast Brazil), is less than $25 \mathrm{~km}$ from the city of Fortaleza (Metropolis) and the International Airport. According to records from the Brazilian Institute of Geography and Statistics (IBGE), as of 2019, Caucaia is the second-largest municipality in Ceará in terms of population (361,400 inhabitants), and GDP is US\$ 1.086 million, occupying an area of $1,227.90 \mathrm{~km}^{2}$ in the northeast portion of Ceará (IPECE 2017).

The Caucaia coast has approximately $45 \mathrm{~km}$ of sandy beaches, $75 \%$ of which consists of beaches with coastal erosion problems (Paula 2015). Currently, of the eight main beaches in the municipality, only Cumbuco Beach still does not show serious signs of coastal erosion. The study area is $14 \mathrm{~km}$ long and is located between the beaches of Tabuba and Cumbuco, on the west end of the Caucaia coast (Fig. 1). This spatial approach allows a comparative analysis of the geospatial behavior of the hotel sector on two neighbouring beaches to the detriment of the coastal erosion process in the region.

The chain of tourist service providers in Caucaia is quite diversified, with hospitality as the main branch. However, we also have to consider the contribution of other services - food, road passenger transport, local fish production (e.g., fish, shrimp, and lobster), sightseeing, and others. Considering public and private investments in the development of tourism in Ceará, Caucaia benefited in different investment phases, which allowed a rapid and concentrated expansion of tourism in the Cumbuco region, becoming the main tourist destination of Ceará visiting Fortaleza (SETUR-CE 2016). Caucaia has strong integration with Fortaleza, favoring spatial, social, and economic relations, streamlining the flow of people, capital, goods, and investments (Gonçalves 2011). 


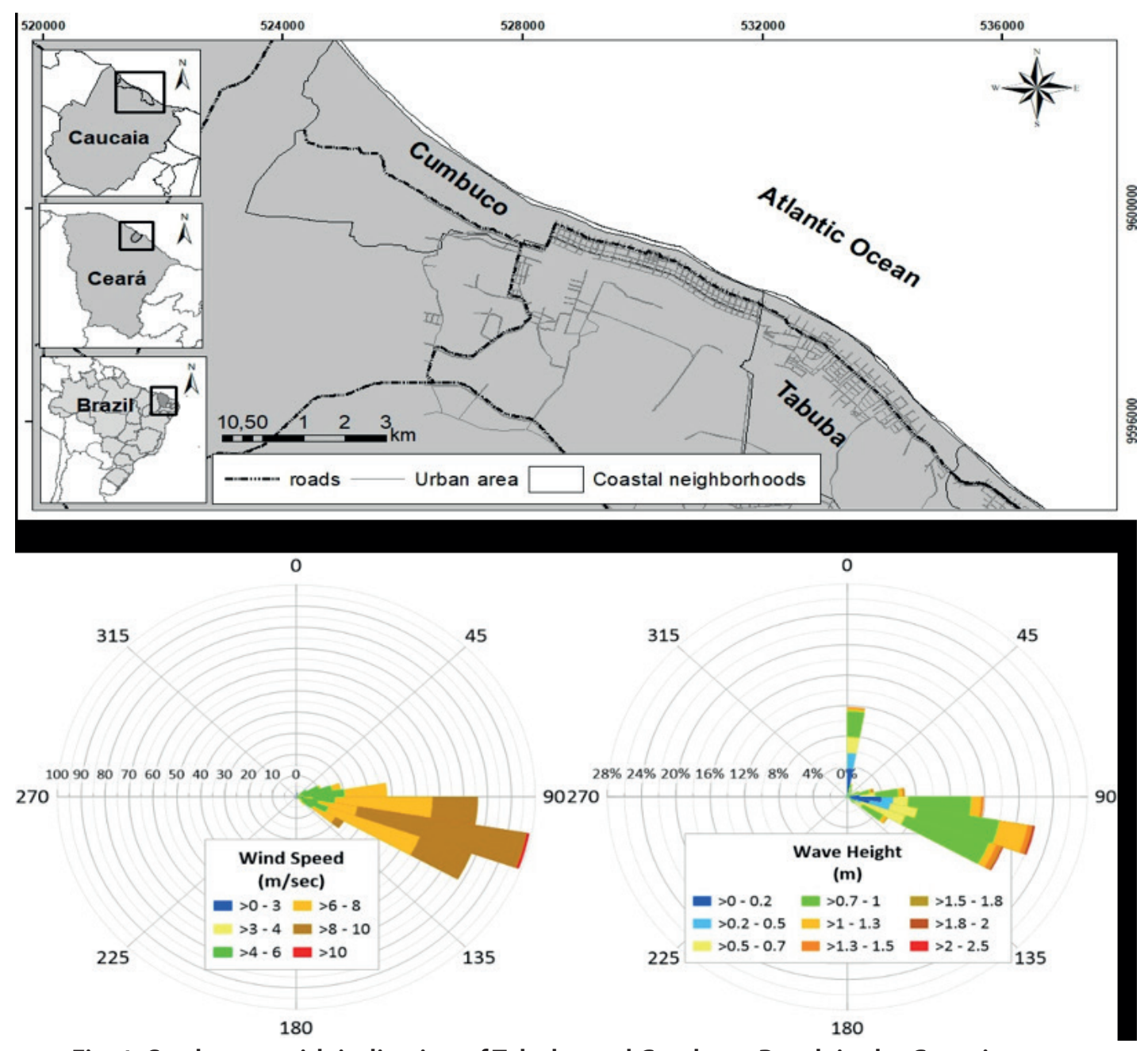

Fig. 1. Study area with indication of Tabuba and Cumbuco Beach in the Caucaia coast

Further, Caucaia has a strong paradigm in the recreational use of its coastline, directly reflected by the environmental stress caused by coastal erosion at Tabuba Beach (Fig. 2a) and the scenic splendor of Praia do Cumbuco (Fig. 2b). In the latter, the best environmental quality generated a massive appropriation of coastal spaces by social and economic actors, attracting major developers in the tourism industry, such as the Portuguese hotel group Vila Galé, which settled in the region in 2010.

According to the report of PRODETUR Nacional 2012, its latest version, entitled «Tourist hubs of Ceará: Tourism marketing plan,» Cumbuco Beach received an A rating for the product Nautical Sports (windsurf and kitesurf). This means that the destination and its characteristics are the main motivators of tourist flows. Tabuba Beach received a $B$ rating. In this category, products that complement the offer of a class A destination are classified and considered strategic to extend the tourists' stay in the region.
Tabuba (4.4 km) and Cumbuco (9.6 km) are urban sandy beaches, with northwest alignment and the presence of dune strands of different generations. The width of the beach strip in Tabuba ranges from $0 \mathrm{~m}$ to $60 \mathrm{~m}$, while that in Cumbuco ranges from $30 \mathrm{~m}$ to $105 \mathrm{~m}$. These values depend on the level of erosion and the amplitude of the tide, which, in the region, can reach $3.3 \mathrm{~m}$, according to the Directorate of Hydrography and Navigation (DHN) of the Brazilian Navy, configuring a mesotidal regime. Seatype waves are more frequent and are associated with the direction and intensity of trade winds, with mean values of significant height ( $\mathrm{Hs}$ ) of $1.33 \mathrm{~m}$, period (Ts) of $7 \mathrm{~s}$, and Mean Direction (Dir.) from the E-SE. Breaking with the dominance of sea waves, swell-type waves occur less frequently, with an average $\mathrm{Hs}$ of $2.4 \mathrm{~m}$, Ts of $14 \mathrm{~s}$, and N-NE Dir.. E-SE winds direction are the most frequent, with an average intensity ranging from $5.1 \mathrm{~m} / \mathrm{s}$ (Jan-Jun) to $9.4 \mathrm{~m} / \mathrm{s}$ (Jul-Dec) (Silva et al. 2011).

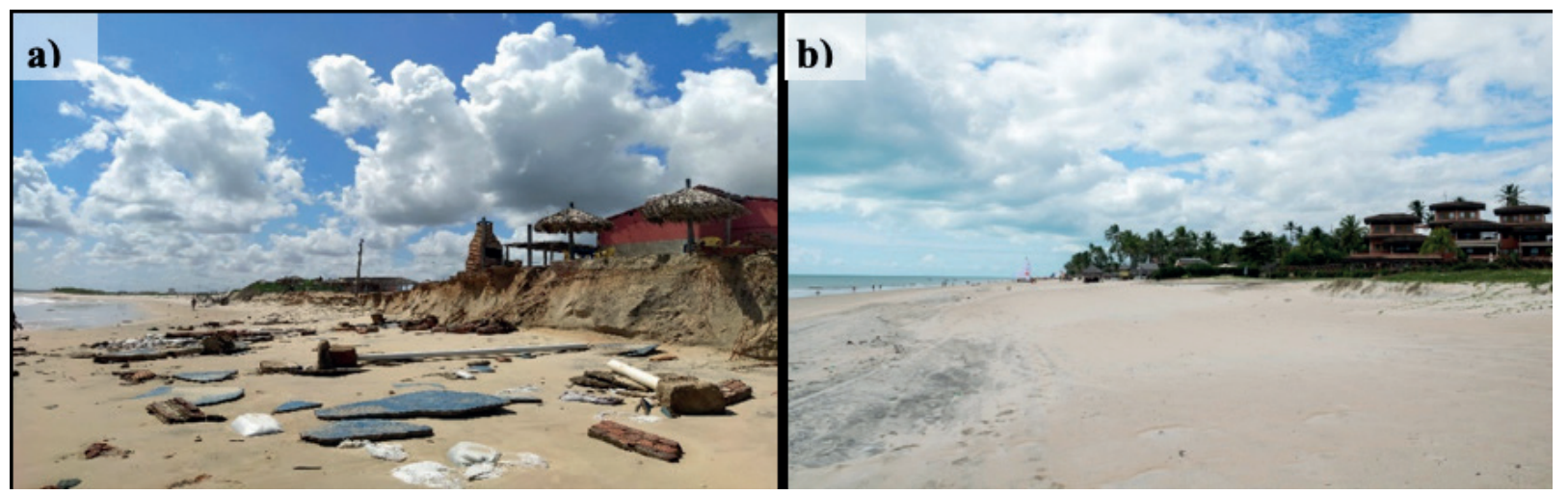

Fig. 2. Coastline situation on the beaches of Tabuba (a) and Cumbuco (b) in February 2020 


\section{MATERIALS AND METHODS}

Shoreline situation

The recent evolution of the coastline between the beaches of Tabuba and Cumbuco was assessed during 2004, 2011, and 2014 using satellite images with different scales and resolutions (Table 1). Orbital images from QuickBird and RapidEye multispectral satellites were used. Remote sensing techniques have been widely used in determining shoreline changes, contributing to accurate information for managing risks and natural disasters (Maglione et al. 2015; Tarmizi et al. 2014; Wikantika et al. 2007). The variation of the coastline due to erosion and sand deposition is a major concern for the management of the coastal zone and its economic activities, such as tourism (White and Asmar 1999).

All images were orthorectified and converted to the Geodetic Reference System adopted in Brazil, with Datum SIRGAS 2000, in the GeoTiff format, and projected using the Universal Transverse Mercator system (UTM, zone 24 South). Images were orthorectified using 30 non-collinear points from the initial image. The points were checked and georeferenced in the field using a GPS/GNSS to obtain the mooring coordinates in the orthorectification process. The selected points in the initial image were corners of rectangular objects (e.g., walls). Thus, the final image was adjusted by the parametric method and distortions eliminated.

Advancements in remote sensing techniques and refinement in the processing and interpretation of satellite images allow for a satisfactory degree, in most cases, to interpret changes in the position of the coastline with greater precision (Liu et al. 2013; Ryu et al. 2002). In recent years, several techniques, and tools (e.g.,
Digital Shoreline Analysis System [DSAS], Processing Algorithms, and Coastal Analysis via Satellite Imagery Engine [CASSIE]) have been developed to improve detection and accuracy in the extraction of the coastline (Liu et al. 2013; Liu and Jezek 2004).

In this study, the coastline was vectored in a GIS environment, with the aid of ArcGIS software. For the beaches of Tabuba and Cumbuco, the total sample of the coastline was $14 \mathrm{~km}, 46.5 \%$ of the Caucaia coastline. For this purpose, the indicator for the vectorization of the shoreline was the maximum range of the wave run-up (Crowell et al. 1991). After extracting the shoreline, the DSAS extension for ArcGIS, developed by the USGS (Thieler et al. 2005), was used to estimate changes in the coastline.

To determine the changes to the shoreline, the positions of the shoreline were incorporated, referenced with the baseline that was determined. The variation of the coastline is determined from the intersections of the transects oriented perpendicularly to the coastline (Kuleli et al. 2011). In this study, transects perpendicular to the coast were generated at $50 \mathrm{~m}$ intervals, with interceptions of 264 transverse transects $300 \mathrm{~m}$ long, perpendicular to the baseline (offshore). The scale adopted for mapping the coastline was 1:3,000 (Fig. 3). In DSAS, the rate of change of shoreline positions (erosion/accretion) was assessed using the end point rate (EPR) and linear regression (LRR) approaches (Thieler et al. 2005).

Erosion and accretion rates for the beaches of Tabuba and Cumbuco were categorized based on the behavior of the coastline identified with the use of DSAS and the application of the LRR parameter. Therefore, according to the indications of Esteves and Finkl (1998) and Luijendijk et al. (2018), the recent evolution of the coastline was grouped into six trend categories: accretion ( $>+0.5 \mathrm{~m} / \mathrm{yr}$ ), stable (between -0.5 and $+0.5 \mathrm{~m} /$

Table 1. General technical specifications of satellite images

\begin{tabular}{|c|c|c|}
\hline Satellite images & & \\
\hline Source & Year & Resolution \\
\hline QuickBird & 2004 & $2.4 \mathrm{~m}$ \\
\hline RapidEye. & 2011 and 2014 & $5 \mathrm{~m}$ \\
\hline
\end{tabular}

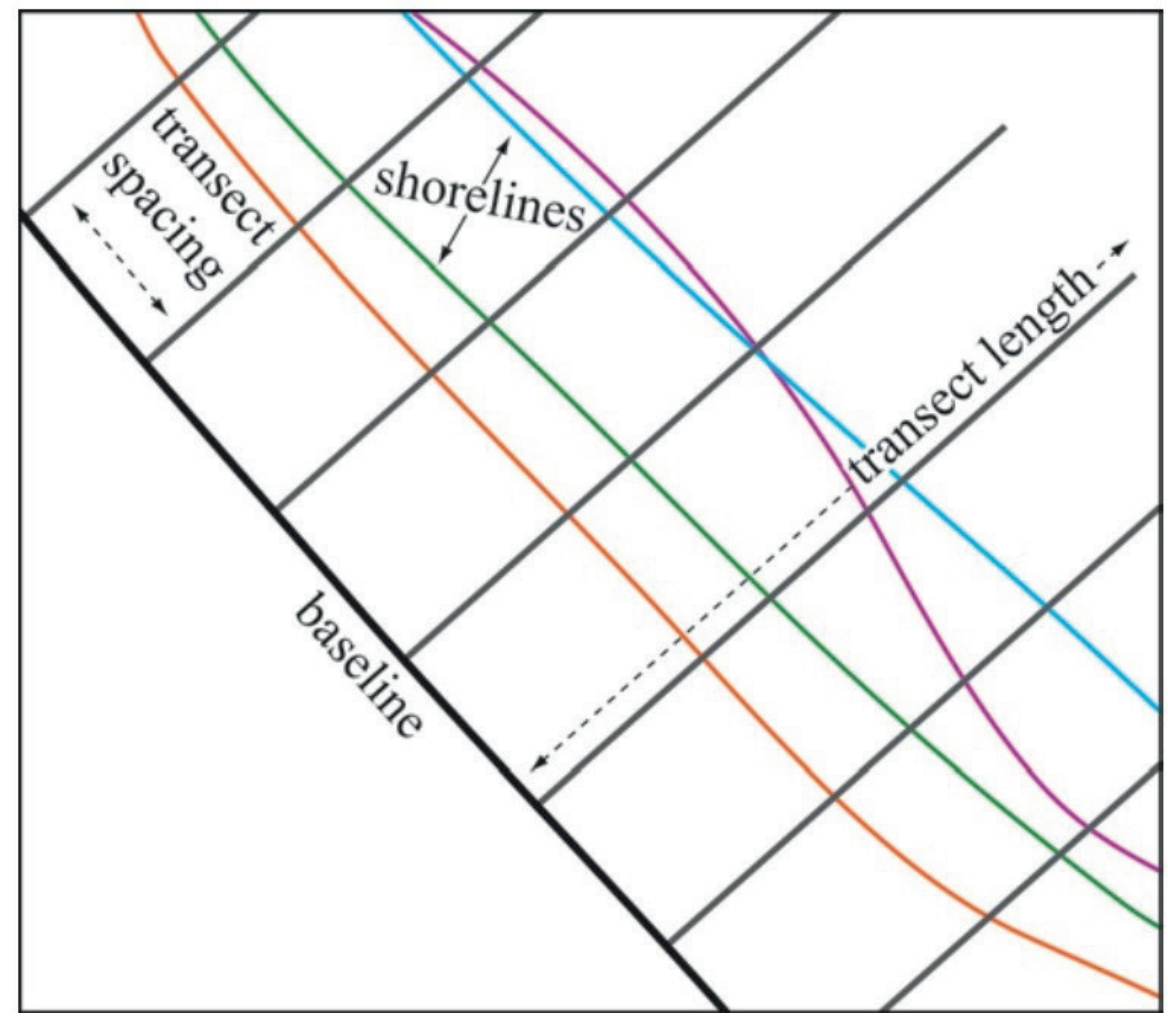

Fig. 3. Launching of transects from the baseline parallel to the shoreline vectors. Source: Thieler et al. (2017) 
$\mathrm{yr}$ ), erosion (between -1 and $-0.5 \mathrm{~m} \mathrm{~m} / \mathrm{yr}$ ), intense erosion (between -3 and $-1 \mathrm{~m} / \mathrm{yr}$ ), severe erosion (between -5 and -3 $\mathrm{m} / \mathrm{yr}$ ), and extreme erosion ( $<-5 \mathrm{~m} / \mathrm{yr}$ ). Finally, field campaigns were conducted between the years 2019 and 2020 to check the shoreline. In the field check, we sought to identify possible indicators of coastal erosion - the high-water mark, remains of building materials, coastal protection structures and rugged dunes. When identified, they were georeferenced with GPS/ GNSS for crossing with the data obtained from the DSAS tool application.

\section{Identification of accommodation facilities and tariffs}

In recent years, the policy of reserving accommodation has undergone significant changes, especially with regard to the cancellation or alteration of reservations (Masieroa et al. 2020). In addition, finding the most suitable means of accommodation for travel plans has become easier and more attractive through digital platforms (e.g., Booking.com, Trivago, TripAdvisor, Hotels. com, Decolar.com, etc.). On these platforms, the tariff is dynamic, promotions are daily, policies are strict, and factors contribute to traveler safety (Masieroa et al. 2020; Mellinas et al. 2016). Further, it is possible to consult all available infrastructure (e.g., parking, swimming pools, internet, sports courts, and accessibility) at the place of accommodation and the opinion of other travelers about that means of accommodation.

The use of these online platforms has been increasingly influencing the decisions of different stakeholders, in which visitors stand out, especially with regard to the sharing of information and experiences on social media platforms, which can directly influence professionals of destination marketing and potential tourists (Tavakoli and Wijesinghe 2019). Thus, the correlation between the products/services offered, prices, locations, and shared traveler experiences are one of the main differentials for the use of online platforms.

The Booking.com platform was chosen as an environment for collecting data on the means of accommodation, as it has easily accessible information and availability for online consultation (Sparks et al. 2016). It is one of the largest digital platforms in the world to consult information on accommodation (Câmara 2013), including allowing a thorough study on the characteristics of the researched means of accommodation, such as the daily rate, types of accommodation, characteristics of accommodation, and others. The daily rates were converted to US dollars according to the quotation date on 08/10/2020 (R\$ $1.00=$ US\$ 0.1854) provided by the Central Bank of Brazil. The booking platform is widely used for data collection and research development, reflecting its reliability and breadth (Ezzaouia and BulchandGidumal 2020; Manes and Tchetchik 2018; Mellinas et al. 2016).

The means of accommodation (e.g., hotels, inns, flats, and hostels) and the daily rates on the beaches of Tabuba and Cumbuco were identified from the information available on Booking.com. It is important to highlight that the public control agencies do not have information on the average value of the individualized accommodation tariff or their location through geographic coordinates. The means of accommodation were identified from the cartographic base of Google Maps, available on the Booking.com platform itself, and later inserted and treated in the Quantum GIS (QGIS) software. After creating the attribute table with the location of the lodging establishments, an edition was made to incorporate the attribute daily rate. Finally, the attribute table was organized with the following variables: code of the means of accommodation (01-111), coordinates (latitude and longitude in SIRGAS 2000), name of the enterprise (alphanumeric code to maintain confidentiality), beach (Tabuba or Cumbuco), and price of the tariff (US\$). Analysis of erosion rate and aspects associated with the means of accommodation was carried out by overlaying maps.

\section{RESULTS AND DISCUSSION}

\section{Shoreline State in the Tabuba and Cumbuco Beaches}

The coastline is an important coastal geomorphological feature in detecting the situation of a beach, especially the problems associated with coastal erosion. It is a dynamic system with rapid responses and evolution. Its tendency can be followed in mapping on different dates through data collection in the field or by satellite imaging (Diniz et al. 2020; Liu et al. 2013). At Tabuba Beach, $59 \%$ of its coastline is affected by erosion, while at Cumbuco Beach, only $11 \%$ of its extension is affected by coastal erosion (Fig. 4).

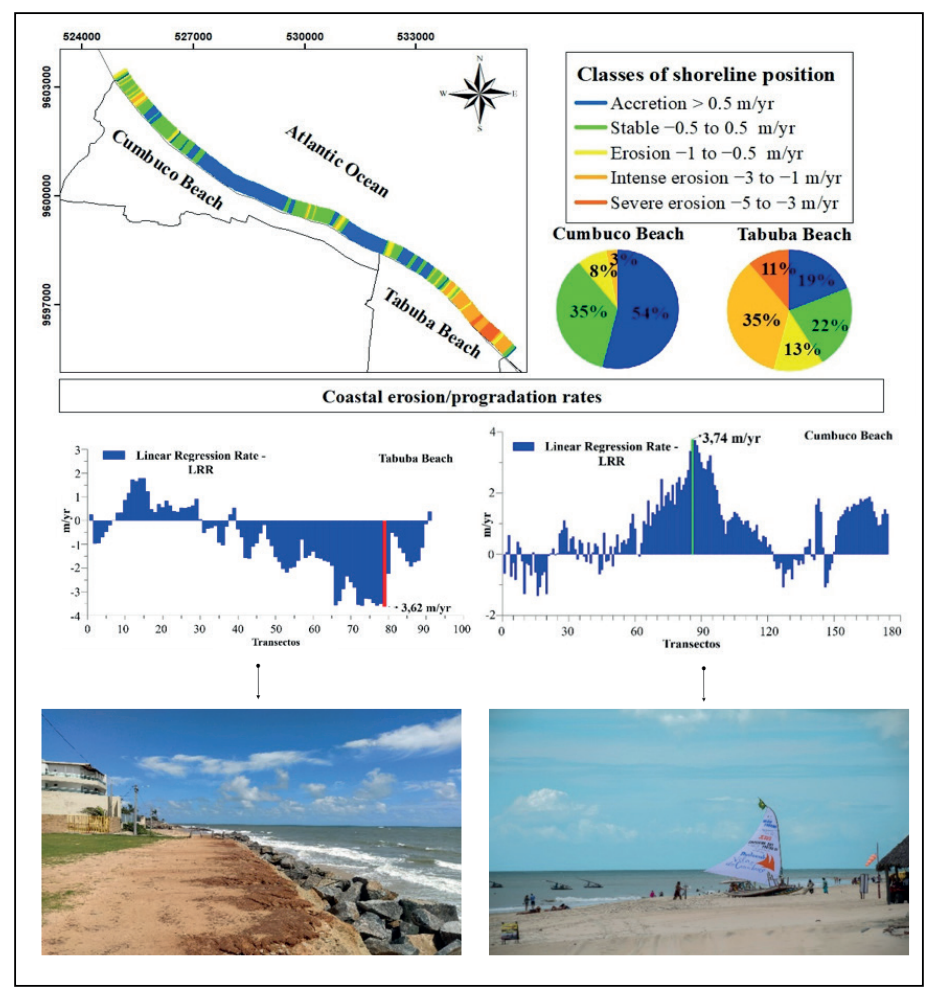

Fig. 4. Rates of shoreline position of the beaches of Tabuba and Cumbuco 
Tabuba Beach is $4.5 \mathrm{~km}$ long and has $59 \%$ of its coastline in the erosion process, of which 35\% are under intense erosion, $13 \%$ in erosion, and $11 \%$ in severe erosion, as proposed by Esteves and Finkl (1998) and Luijendijk et al. (2018). The remaining $41 \%$ are either stable or increasing. On this beach, maximum rates of coastal erosion of up to $3.62 \mathrm{~m} / \mathrm{yr}$ were recorded. The eastern sector of this beach concentrates the highest erosion rates, experiencing an average retreat of the coastline on the order of $2.8 \mathrm{~m}$ $\mathrm{m} / \mathrm{yr}$. In the western sector, there are stretches with an average retreat of $1.5 \mathrm{~m} / \mathrm{yr}$ and an average increase in beach range of $0.5 \mathrm{~m} / \mathrm{yr}$. Coastal erosion at Tabuba Beach follows the pattern of this coast, where coastal erosion has been moving from east to west from the municipality of Fortaleza to that of Caucaia. With the latter, the coastal erosion process has progressively affected all beaches east of Tabuba in the last 30 years, including Leblon Park, Iparana, Pacheco and Icaraí. This process is well evidenced by the numerous coastal protection infrastructures built between the cities of Fortaleza and Caucaia (Paula 2015).

Cumbuco Beach is the longest on the Caucaia coast, with approximately $9.6 \mathrm{~km}$ of sandy beaches in the presence of coastal dunes. Its situation in relation to coastal erosion is different from Praia da Tabuba, as 54\% of its shoreline shows an accretion trend that is, there is an increase in the beach range, with a maximum record of $3.74 \mathrm{~m} / \mathrm{yr}$. Another $35 \%$ of the total length of the coastline is stable and has no apparent evidence of coastal erosion. Therefore, of $89 \%$ of the coastline of Cumbuco Beach, there is no evidence of coastal erosion, which is a significant situation for continuous coastal development based on sun, beach, and wind tourism. Finally, only $11 \%$ of this coastal stretch shows any indication of coastal erosion, reaching a maximum rate of $1.5 \mathrm{~m} / \mathrm{yr}$. This erosion rate is $58.5 \%$ lower than the rate recorded at Tabuba Beach, focusing mainly on the stretch below the boundary between the two beaches, which can mean continuity of the erosion process, which, in Caucaia, always goes toward the west, as is the case here.

Coastal erosion in this stretch of the Caucaia coast is well advanced along Praia da Tabuba, directly reaching the urbanized marine front, which is formed by summer residences and a few structures aimed at tourist development. This is the case for some inns and beach huts. The natural coastal landscape has been progressively modified due to the advance of the sea and the construction of coastal protection works. In total, seven rockfills are protecting $700 \mathrm{~m}$ of the urbanized marine front that were built between 2014 and 2019 (Fig. 5). The beach is mainly used for leisure as sunbathing and sea; however, the level of use of the beach is low, as the largest flow of visitors is directed Cumbuco Beach (IPETURIS 2011). Up to the time of this study, no coastal protection structure has been identified in Cumbuco Beach because, in the few places where the erosion problem manifests, there are no urban constructions. Therefore, there is no need to insert any defense apparatus from the coast.

Cumbuco is extremely popular throughout the year, as it has the best service equipment for the tourist sector. In addition, services for tourists are more diverse in the region, ranging from accommodation to windsurfing and kite surfing schools (IPETURIS 2011). The installation of tourist equipment such as Chico do Caranguejo beach hut and the Carmel Cumbuco Resort (Fig. 6) are highlighted, showing infrastructure development for tourists between the years 2004 and 2019.
2004

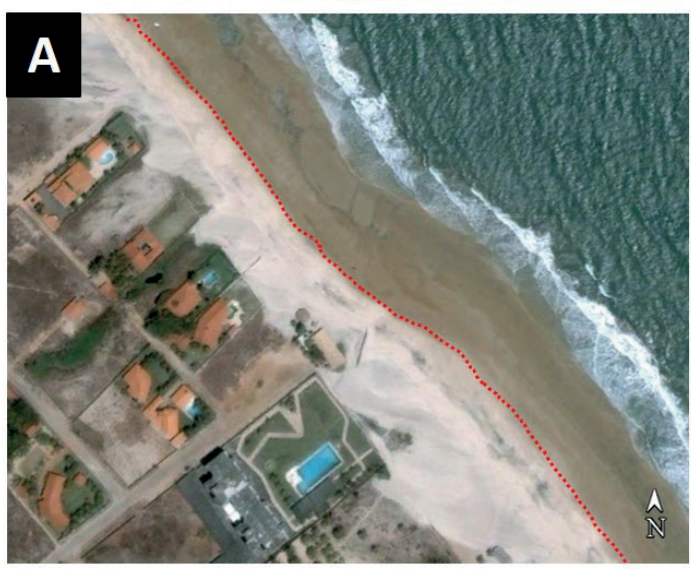

2014

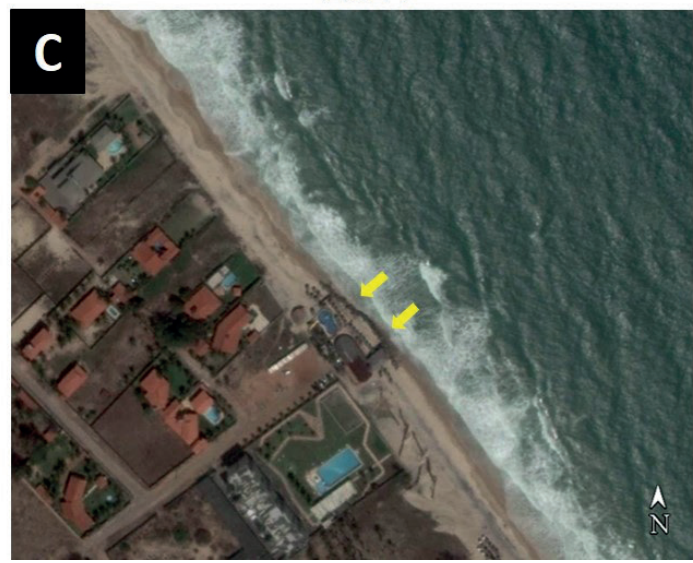

\section{2}

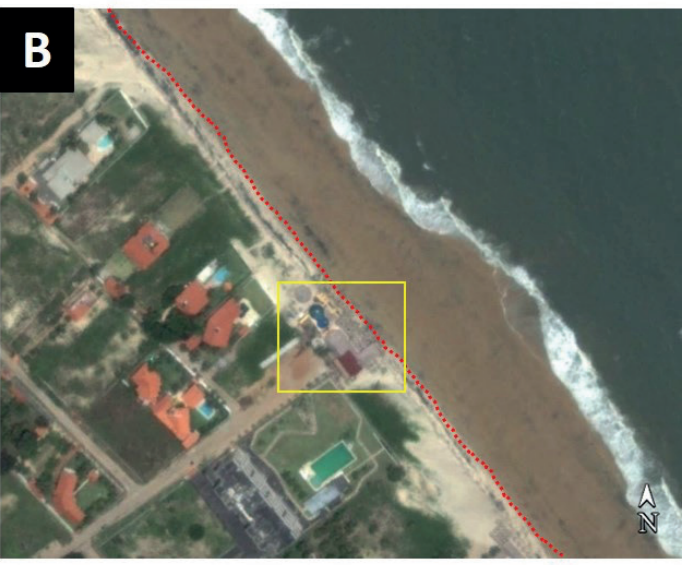

2019

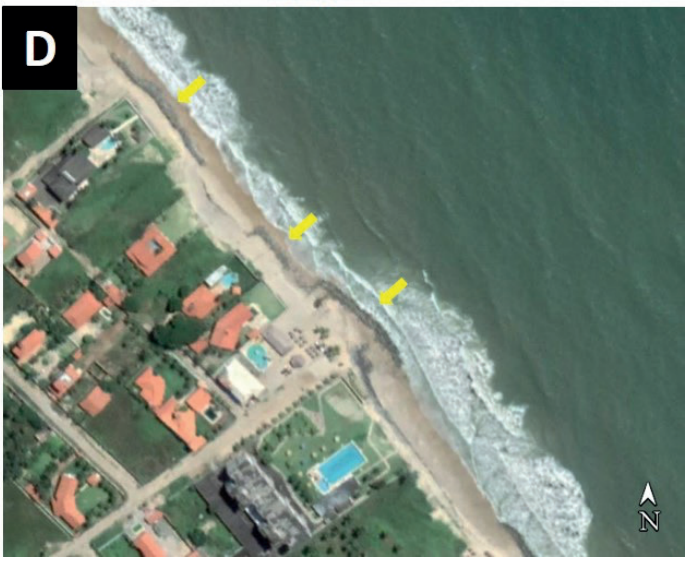

Fig. 5. A stretch of Tabuba Beach in different dates. A) in 2004, the edge between dry and wet sand (red striped line); B) in 2012, the yellow square indicate the place of a beach hut; C) and D) indicate the presence of rockfills (indicated by the yellow arrows) to contain the progress of erosive processes. Source: Google Earth 


\section{4}

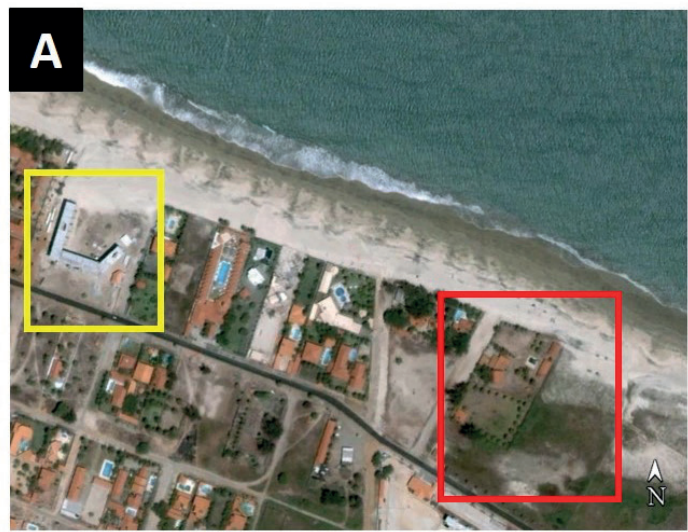

2014

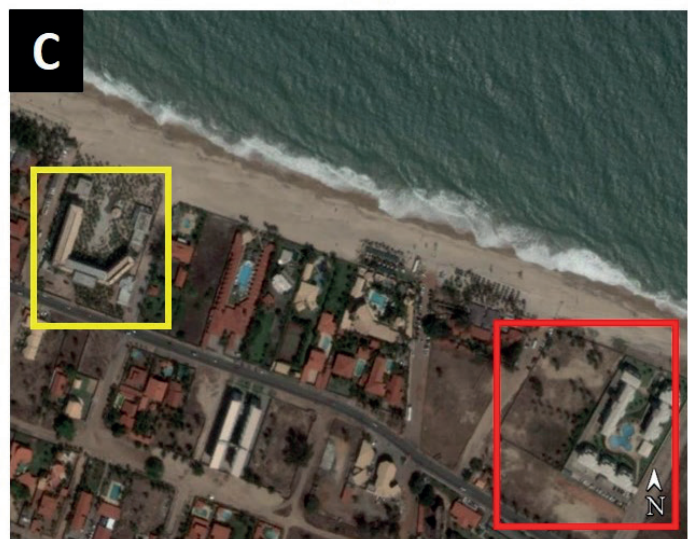

2012
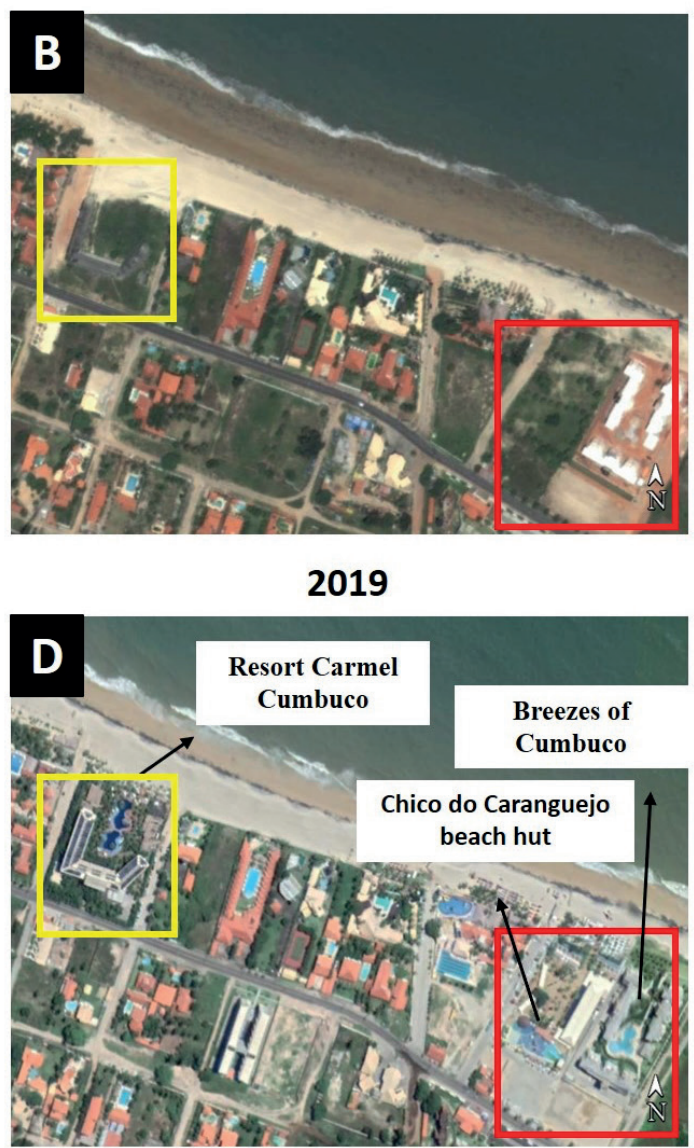

Fig. 6. A stretch of Cumbuco Beach. The yellow and orange rectangles highlight the spaces in which tourism equipment were built. Source: Google Earth

Distribution of Tourist Accommodation Facilities and daily rates in the Tabuba and Cumbuco Beaches

Considering the potential for attractiveness, the beaches of Tabuba and Cumbuco stand out as the main tourist destinations on the coast of Caucaia (Lopes 2015), the most visited in Ceará by tourists via the city of Fortaleza (SETUR 2020). Considering the tourist accommodation facilities, 111 means of accommodation were identified (e.g., apartments, resorts, hostels, houses, hotels, and inns), with only 11 of these (9.9\%) being installed in Tabuba Beach, being in mostly small accommodation establishments. In contrast to the low attractiveness of Tabuba Beach to the installation of accommodation facilities, Cumbuco Beach concentrates more than $90 \%$ of all tourist accommodations. This reflects its better environmental quality compared to Tabuba Beach, which suffers from a severe coastal erosion (Fig. 7). This situation is reflected in the attractiveness of large tourist complexes, such as Vila Galé Cumbuco Resort and others installed in this region.

The advanced stage of erosive processes on the beach directly impacts coastal tourism, that is, the local economy that is directly linked to this activity. The reduced number of lodging facilities in Tabuba Beach shows the low economic dynamism of the location, especially in sectors with significant local economic impact - service and trade - especially when we consider that more than $60 \%$ of the GDP of the municipality of Caucaia comes from sector services (IPECE 2017).

The implementation of large tourist facilities, such as the resorts at Cumbuco Beach, takes place through foreign and national investments, configuring the location as a «tourist enclave» targeted by planned actions that focus on a group of national and international tourists, highlighting its hotel infrastructure software (Mesquita 2014). Cumbuco is thus a top tourist destination not only on the coast of Caucaia but also in the state of Ceará (Lopes 2015).

The high standard of consumption and the best environmental quality of the beaches can be seen from the value practiced in the hosting plan, such as the charge per night in the means of accommodation (Fig. 8). More specifically, in Caucaia, among the lodging facilities installed on the beaches of Tabuba and Cumbuco, the daily rate ranged from US\$ 7.42 to US\$278.86, a standard deviation of US\$191.90, which shows a high degree of dispersion in the daily rates on the beaches in question. This is due to several factors, including the environmental quality of the place, the standard of facilities for tourist accommodations, and the diversity of services available to the visitor.

In Tabuba, the average daily rate recorded on Booking. com was US\$ 56.01, with a minimum of US 7.42 and a maximum of US\$278.86. At Praia do Cumbuco, the average value was US\$ 50.57, with the same minimum and maximum variation recorded for Praia da Tabuba. This average daily rate in Cumbuco, below that recorded in Tabuba, is explained by the greater number of accommodations with an average price of US\$7.42, generally associated with the offer of vacancies in hostels. However, in Cumbuco, almost all the enterprises with a daily value above US\$ 87.15 are installed, a re-signified value by the existence of large hotel developments and luxury resorts (Fig. 9). Finally, between these two beaches, it is possible to observe a wide variety of prices practiced in the daily rate, in which the environmental situation and the size of the enterprise are important elements in the composition of the tariff of the means of accommodation. 


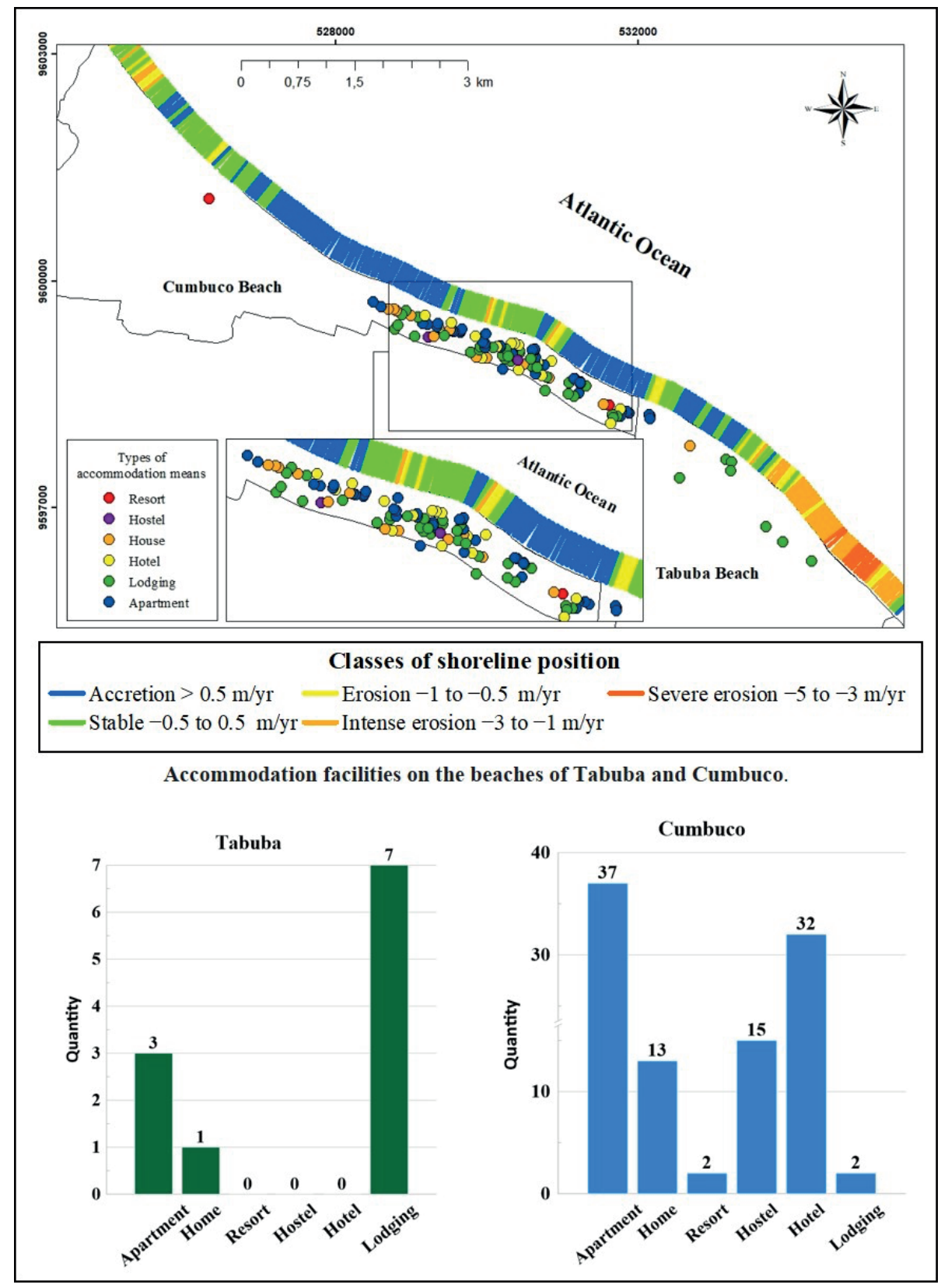

Fig. 7. Distribution of types of lodging in the beaches of Tabuba and Cumbuco

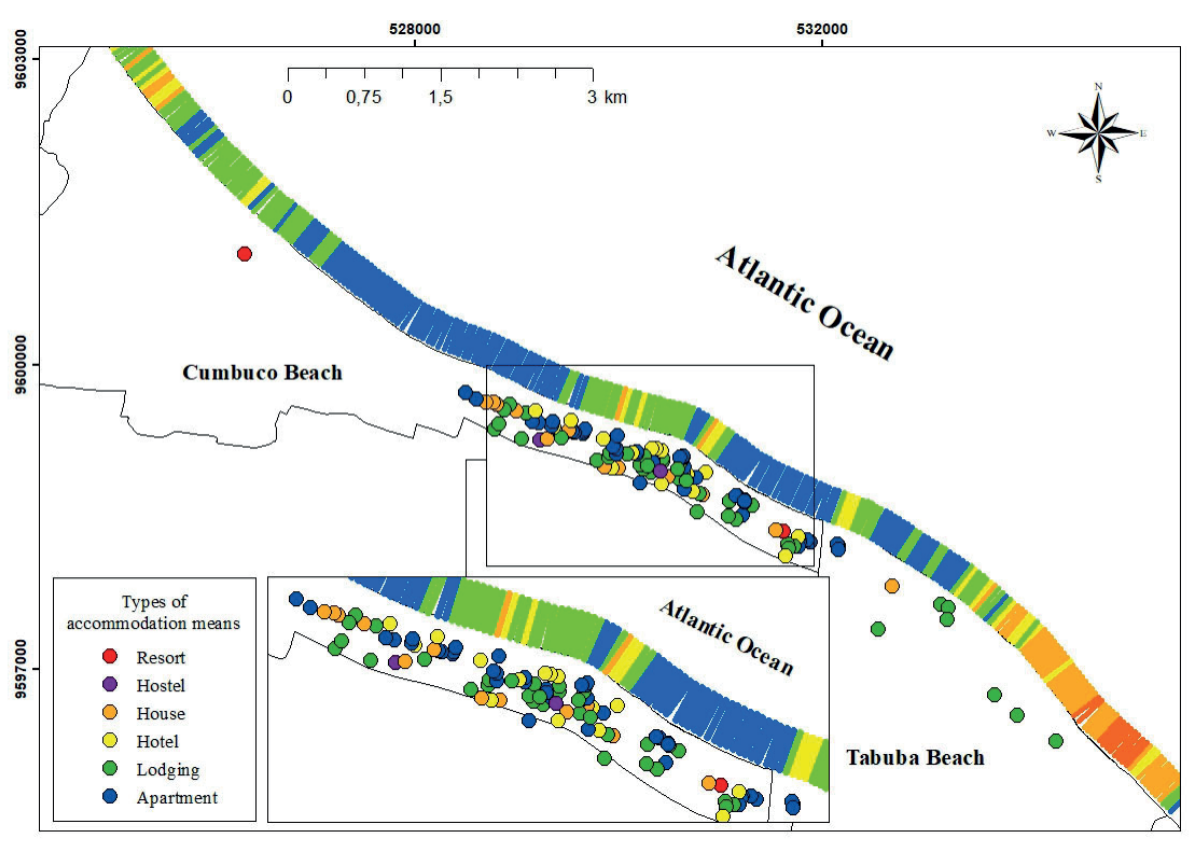

Fig. 8. Distribution of the daily rates (US\$) of the lodging facilities on the beaches of Tabuba and Cumbuco 


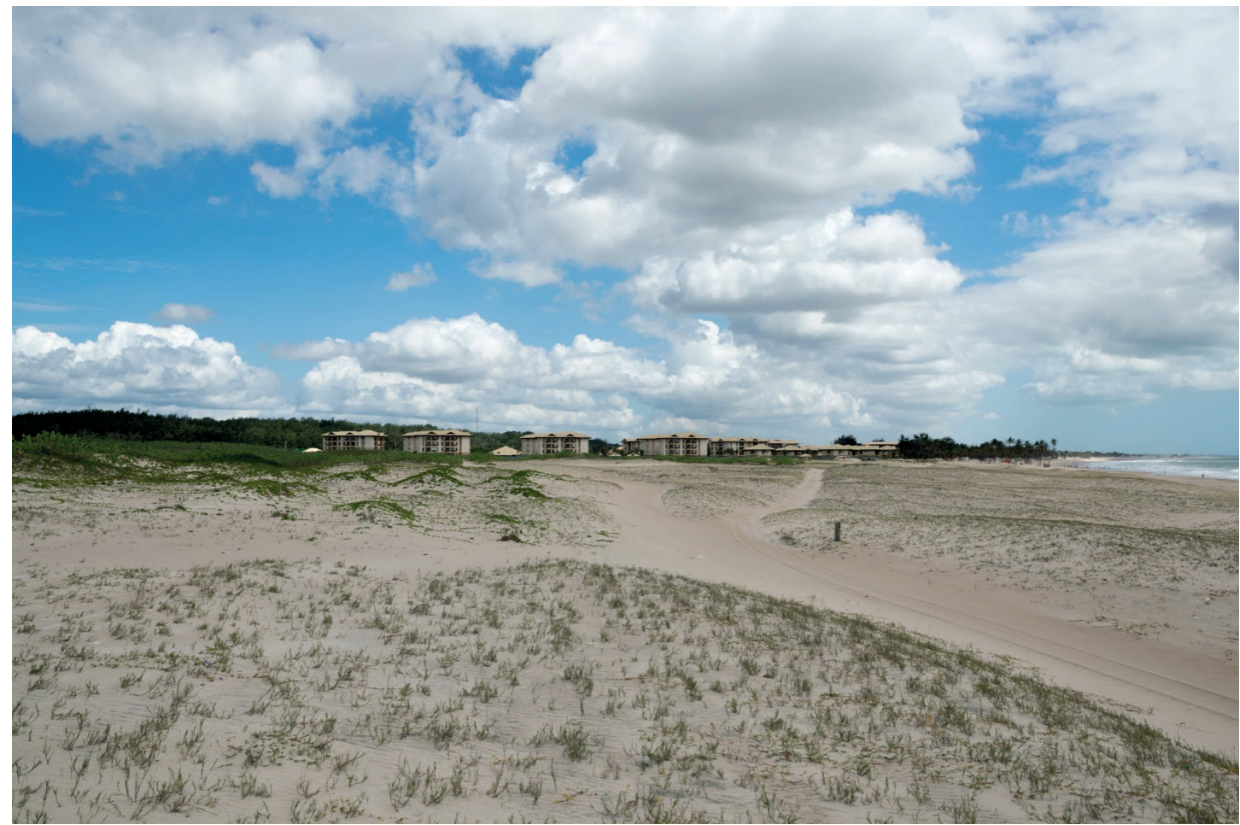

Fig. 9. Presence of luxury resorts in Praia do Cumbuco in the middle of the dune and coconut groves, registering the high standard of some accommodations in this sector of the Caucaia coast

Therefore, the large concentration of touristinfrastructure in the high-end hotel sector generates speculation in several other sectors of the economy, such as the food sector, service, commerce, industry, and civil construction, generating employment, investments, and revenue collection for the Caucaia municipality. Notably, the consolidation of the Cumbuco location as a «mandatory destination» for tourists is not only due to its hotel infrastructure but also because of the potential for the attractiveness of its beach, with several activities being offered for leisure and recreation, boosting the offer of various sectors of the economy. Allied to this, the better environmental quality of the beach and the fact that it is not affected by coastal erosion contributes to it being the main destination for tourists who enter Ceará via Fortaleza.

Coastal erosion is a factor that inhibits the instigation of new tourist accommodations at Tabuba Beach. Thus, one way to attract new tourist developments to Tabuba Beach would be to invest in coastal protection with environmental recovery. Currently, there are several seawalls installed along this beach, but they are ineffective in neutralizing the problem and in restoring the beach. In this case, government intervention would be important, as individual initiatives do not have the expected effect. In terms of recommendation, there could be an investment in actions with the conception building with nature (van den Hoek et al. 2012; de Vriend et al. 2015; Hoonhout and Vries 2017) - is a method, that to seek solutions that integrate environment and maritime infrastructure construction (e.g., Sand Motor Project).

\section{CONCLUSIONS}

The use of geoprocessing techniques is one of the main tools in environmental studies as well as necessary for territorial (re)ordering of coastal areas, especially in areas affected by the occurrence of erosion processes. The generation of data regarding the rates of erosion, stability, and progradation associated with the collection of information regarding the lodging facilities helped construct a framework that apprehended the performance of erosive processes on the hotel sector in Tabuba and Cumbuco.

The analysis conducted in this study indicates that the Caucaia coast has been progressively impacted by erosive processes in recent years. Of the $13.9 \mathrm{~km}$ of coastline analyzed-46.3\% of the entire coastline-it was found that erosive trends are present in $26.8 \%$ of the coast of the analyzed coast; of these, $9 \%$ are erosion $(-0.5$ to $-1 \mathrm{~m} / \mathrm{yr})$, $14.4 \%$ intense erosion ( -3 to $-1 \mathrm{~m} / \mathrm{yr}$ ), and $3.4 \%$ severe erosion ( -5 to $-3 \mathrm{~m} / \mathrm{yr}$ ).

The shoreline changes on the beaches of Tabuba and Cumbuco has produced antagonistic effects on coastal development, affecting beach businesses unevenly, as is the case with the hotel sector. The trends of progradation are verified mainly in Cumbuco Beach, presenting consequently better environmental quality in terms of area for conducting recreational activities.

The occurrence of erosion processes was more intense in Tabuba Beach, where the occurrence of coastal containment structures was identified to protect beach huts, evidencing the progress of erosion processes in the locality, generating direct impacts on the local economy. The spatial distribution of the lodging facilities indicates that Tabuba Beach do not constitute a location of interest aimed at mass tourism and, consequently, do not encourage the development of economic activities linked to this sector, in addition to the local devaluation due to erosive processes. In the locality of Cumbuco, where the beach is in a good state of conservation, there are several accommodation options, with the presence of resorts, generating commercial speculation that streamlines the local economy, expanding investments in trade, service, industry, and civil construction.

With that, it can be said that erosion processes tend to progress along Tabuba Beach, limiting the demand of this beach by investors in the accommodation sector. However, it is not evident in Cumbuco, where the real estate market is heated, and the demand for land construction of accommodation equipment is increasing, evidencing the best environmental quality of the place. Thus, it is necessary to apply measures aimed at the conservation and monitoring of coastal environments, which are essential for the municipality's economic development, especially for the tourist sector.

Finally, it is possible to confirm that coastal erosion directly affects the choice of location for installing a tourist accommodation. However, other variables of tourist attractiveness can also affect the location option for instituting a tourist accommodation. Thus, we suggest that other studies look at variables such as: distance of the coastal zone from the continental places of residence (cities) and urban infrastructure. 


\section{REFERENCES}

Alexandrakis G., Manasakis C. and Kampanis N. (2015). Valuating the effects of beach erosion to tourism revenue. A management perspective. Ocean \& Coastal Management, 111, 1-11.

Antonakakis N., Dragouni M. and Filis G. (2015). How strong is the linkage between tourism and economic growth in Europe? Economic Modelling, 44, 142-155.

Araujo E. and Pereira A. (2011). O turismo e a valorizacão do litoral metropolitano: espacialidade turística em Caucaia-CE. Raega-O Espaço Geográfico em Análise, 21, 78-104.

BRASIL (2012). Polos Turísticos do Ceará: Plano de Marketing Turístico. Prodetur Nacional, Brasilia.

Burak S., Dog an E. and Gaziog lu C. (2004). Impact of urbanization and tourism on coastal environment. Ocean \& Coastal Management, 47, 515-527.

Câmara E. (2013). O comércio eletrônico e o turismo. Dissertação (Mestrado em Gestão/MBA) - Departamento de Economia e Gestão, Universidade dos Açores.

Crowell M., Leatherman S. and Buckley M. (1991). Historical shoreline change: error analysis and mapping accuracy. Journal of Coastal Research, Flórida, 7, 839-852.

Cruz R. (2003). Introdução a Geografia do Turismo. 2, São Paulo: Roca.

Diniz M., Silva D., Santos J., Souza R. and Silva, J. (2020). Variation of the Coastline Between the Years of 1984 and 2017 in the State of Sergipe, Northeast Region, Brazil. Journal of Coastal Research, 95, 458.

Dogru T. and Bulut U. (2018). Is tourism an engine for economic recovery? Theory and empirical evidence. Tourism Management, 67, 425-434.

Dogru T., Sirakaya-Turk E. and Crouch G. (2017). Remodeling international tourism demand: Old theory and new evidence. Tourism Management, 60, 47-55.

Esteves L. and Finkl C. (1998). The problem of critically eroded areas (CEA): An evaluation of Florida beaches. Journal of Coastal Research, 26, 11-18.

Ezzaouia I. and Bulchand-Gidumal J. (2020). Factors influencing the adoption of information technology in the hotelindustry. An analysis in a developing country. Tourism Management Perspectives, 34, 1-10.

Fuchs M., Höpken W. and Lexhagen M. (2014). Big data analytics for knowledge generation in tourism destinations - A case from Sweden. Journal of Destination Marketing \& Management, 3, 198-209.

Gonçalves T. (2011). Região Metropolitana de Fortaleza: o município de Caucaia na dinâmica de integração e mobilidade intrametropolitana. Caminhos de Geografia, 12, 144-154.

Holden A. (2000). Environment and tourism. London: Routledge.

Hoonhout B. and Vries S. (2017). Field measurements on spatial variations in aeolian sediment availability at the Sand Motor mega nourishment. Aeolian Research, 24, 93-104.

IBGE (2019). Pesquisa Mensal de Serviços. Rio de Janeiro. Available at: https://www.ibge.gov.br/estatisticas/economicas/servicos/9229pesquisa-mensal-de-servicos.html?=\&t=o-que-e. [Accessed 05 Jan. 2021].

IPECE (2017). Perfil Municipal de Caucaia. Fortaleza: IPECE, 2017. Available at: https://www.ipece.ce.gov.br/wp-content/uploads/ sites/45/2018/09/Caucaia_2017.pdf. [Accessed 20 Dec. 2020].

IPETURIS (2011). Estudos de mercado dos polos turísticos do PRODETUR nacional no Estado do Ceará. Available at: http://www.setur. ce.gov.br/images/PDFs/PRODETUR/produto-7-consolidacao-estudos.pdf. [Accessed 03 Aug. 2020].

Kuleli T., Guneroglu A., Karsli F. and Dihkan M. (2011). Automatic detection of shoreline change on coastal Ramsar wetlands of Turkey. Ocean Engineering, 38, 1141-1149.

Ladhari R. and Michaud M. (2015). EWOM effects on hotel booking intentions, attitudes, trust, and website perceptions. International Journal of Hospitality Management, 46, 36-45.

Lakshmi S. and Shaji T. (2016). Transformation of Coastal Settlements Due to Tourism. Procedia Technology, 24, 1668-1680.

Lee C. and Chang, C. (2008). Tourism development and economic growth: a closer look at panels. Tourism Management, 29 (1), $180-192$. Lima J. and Paula D. (2017). Serviços Ecossistêmicos em Litorais Urbanos: o Caso de Fortaleza, Ceará, Brasil. In: Perez Filho, A. \& Amorim, A. A. (Org.). Os desafios da Geografia Física na fronteira do conhecimento. Campinas: Instituto de Geociências, 1, $2940-2945$.

Liu H. and Jezek K. (2004). Automated extraction of coastline from satellite imagery by integrating Canny edge detection and locally adaptive thresholding methods. Int. J. Remote Sensing, 25, 937-958.

Liu Y., Hunag H., Qiu Z. and Fan J. (2013). Detecting coastline change from satellite images based on beach slope estimation in a tidal flat. International Journal of Applied Earth Observation and Geoinformation, 23, 165-176.

Lopes F. (2015). Os destinos turísticos face às populações locais: intervenções, efeitos e práticas na Praia do Cumbuco, Ceará, Brasil. Revista Iberoamericana de Turismo-RITUR, 5, Número Especial, 70-80.

Luijendijk A., Hagenaars G., Ranasinghe R., Baart F., Donchyts G. and Aarninkhof S. (2018). The State of the World's Beaches. Scientific Reports, 1, 1-11.

Maglione P., Parente C. and Vallario A. (2014). Coastline extraction using high resolution WorldView-2 satellite imagery. European Journal of Remote Sensing, 47, 685-699, DOI: 10.5721/EuJRS20144739.

Manes E. and Tchetchik, A. (2018). The role of electronic word of mouth in reducing information asymmetry: An empirical investigation of online hotel booking. Journal of Business Research, 85, 185-196.

Masieroa L., Vigliab G. and Nieto-Garciab M. (2020). Strategic consumer behavior in online hotel booking. Annals of Tourism Research, $83,1-13$.

Mellinas J., María-Dolores S. and García J. (2016). Effects of the Booking.com scoring system. Tourism Management, $57,80-83$.

Mesquita Á. (2014) Diagnóstico da reestruturação espacial e da dinâmica socioambiental provocadas pelo turismo na orla do Cumbuco - Caucaia - Ceará - Brasil. Dissertação (Mestrado em Desenvolvimento e Meio Ambiente) - Centro de Ciências, Universidade Federal do Ceará. 65-78.

Mihalic T. (2000). Environmental management of a tourist destination: A factor of tourism competitiveness. Tourism management, 21, 
Nicholls R. (2011). Planning for the Impacts of Sea Level Rise. Oceanography, 24, 144-157.

Paula D. (2015). Erosão costeira e estruturas de proteção no litoral da Região Metropolitana de Fortaleza (Ceará, Brasil): um contributo para artificialização do Litoral. REDE-Revista Eletrônica do PRODEMA, 9, 73-86.

Peña-Alonso C., Hernández-Calvento L., Pérez-Chacón E. and Ariza-Solé E. (2017). The relationship between heritage, recreational quality and geomorphological vulnerability in the coastal zone: A case study of beach systems in the Canary Islands. Ecological Indicators, 82, 420432.

Phillips M. and Jones A. (2006). Erosion and tourism infrastructure in the coastal zone: problems, consequences and management. Tourism Management, 27, 517-524.

Roca E., Villares M. and Ortego M. (2009). Assessing public perceptions on beach quality according to beach users' profile: a case study in the costa brava (Spain): A case study in the Costa Brava (Spain). Tourism Management, 30, 598-607.

Ryu J., Won J. and Min K. (2002). Waterline extraction from Landsat TM data in a tidal flat. A case study in Gomso bay, Korea. Technical Report Series, vol. 83, Department of Geography and Anthropology Lousiana State University, 442-456.

Seghir G., Mostéfa B., Abbes S. and Zakarya G. (2015). Tourism Spending-Economic Growth Causality in 49 Countries: a dynamic panel data approach. A Dynamic Panel Data Approach. Procedia Economics and Finance, 23, 1613-1623.

Semeoshenkova V. and Newton A. (2015). Overview of erosion and beach quality issues in three Southern European countries: Portugal, Spain and Italy. Ocean \& Coastal Management, 118, 12-21.

SETUR (2016). Evolução recente do turismo no Ceará 2006/16. Fortaleza-CE.

SETUR (2020). Indicadores Turísticos. Fortaleza-CE.

Silva A., Façanha P., Bezerra C., Araujo A. and Pitombeira, E. (2011). Características das ondas «sea» and «swell» observadas no litoral do Ceará-Brasil: variabilidade anual e inter-anual. Tropical Oceanography, 39, 123-132.

Silva M. and Lima, A. (2015). Turismo e o Litoral leste do Ceará. Boletim Gaúcho de Geografia, 42(1), 173-194.

Sparks B., So K. and Bradley G. (2016). Responding to negative online reviews: the effects of hotel responses on customer inferences of trust and concern. Tourism Management, 53, 74-85.

Stive M., Ranasinghe R. and Cowell P. (2009). Sea Level Rise and Coastal Erosion. Handbook of Coastal and Ocean Engineering, 10231037.

Tarmizi N., Samad A. and Yusop S. (2014). Qualitative and Quantitative Assessment on Shoreline Data Extraction from Quickbird Satellite Images. IPASJ International Journal of Computer Science (IIJCS).

Tavakoli R. and Wijesinghe S. (2019). The evolution of the web and netnography in tourism: A systematic review. Tourism Management Perspectives, 29, 48-55.

Thieler E., Himmelstoss E., Zichichi J. and Ergul A. (2017). Digital Shoreline Analysis System (DSAS) version 4.0 - An ArcGIS extension for calculating shoreline change (ver.4.4, July 2017): U.S. Geological Survey Open-File Report 2008-1278 Available at: https://pubs.er.usgs.gov/ publication/ofr20081278. [Accessed 20 jun. 2018].

Thieler E., Himmelstoss E., Zichichi J. and Miller T. (2005). Digital Shoreline Analysis System (DSAS) version 3.0: an ArcGIS extension for calculating shoreline change. US Geological Survey Open-File Report, 1304.

UNWTO (2018). Global and regional tourism performance 2018. UNWTO. Available at: https://www.unwto.org/global-and-regionaltourism-performance. [Accessed 25 de aug. de 2020].

Van den Hoek R., Brugnach M. and Hoekstra A. (2012). Shifting to ecological engineering in flood management: Introducing new uncertainties in the development of a Building with Nature pilot project. Environmental Science \& Policy, 22, 85-99.

Van der Meulen F., Misdorp R. and Baarse G. (2001). ICZM, from planning to implementation: Success or failure? In E. Ozhan (Ed.), Medcoast 01: Proceedings of the fifth international conference on the Mediterranean Coastal environment, 1, 1-16. Ankara: Medcoast.

Vousdoukas M., Ranasinghe R., Mentaschi L., Plomaritis T., Athanasiou P., Luijendijk A. and Feyen L. (2020). Sandy coastlines under threat of erosion. Nature Climate Change, 10, 260-263.

Vriend H., Koningsveld M., Aarninkhof S., Vries M., Baptist M. (2015). Sustainable hydraulic engineering through building with nature. Journal of Hydro-environment Research, 9, 2, 159-171.

White K. and Asmar H. (1999). Monitoring changing position of coastlines using Thematic Mapper imagery, an example from the Nile Delta. Geomorphology, 29, 93-105.

Wikantika K., Sinaga A., Hadi F. and Darmawan S. (2007). Quick assessment on identification of damaged building and land-use changes in the post - tsunami disaster with a quick-look image of IKONOS and Quickbird (a case study in Meulaboh City, Aceh). International Journal of Remote Sensing, 28, 3037-3044.

Wu J. and Law R. (2019). Analysing behavioural differences between e- and m-bookers in hotel booking. International Journal of Hospitality Management, 83, 247-256.

Zhang K., Douglas B. and Leatherman S. (2004). Global warming and coastal erosion. Climatic Change, 64, 41-58. 